Примљен: 2. новембра 2020.

Прихваћен: 9. фебруара 2021.

Тијана И. Балек ${ }^{1}$

https://doi.org/10.46630/phm.13.2021.45

Универзитет у Новом Саду

Филозофски факултет ${ }^{2}$

Одсек за славистику

\title{
МОРФОСИНТАКСИЧКЕ И ПРАГМАТИЧКЕ ОСОБИНЕ ГЛАГОЛА ЛЮБИТЬ(СЯ) И ВОЛЕТИ (СЕ) КАО ЕКСПОНЕНАТА ГЛАГОЛА СА ЗНАЧЕЊЕМ ПОЗИТИВНИХ ОСЕКАҢА У РУСКОМ И СРПСКОМ ЈЕЗИКУ
}

У раду се сагледавају лексикографске, морфосинтаксичке и прагматичке особине глагола позитивно денотираних осећања у руском и српском језику - любить и волети, као и њихових рефлексивних облика - любиться и волети се у циљу дефинисања категоријалних карактеристика које би у потоњим истраживањима глаголске лексике с истоветним или сличним значењем служиле као демаркациони критеријуми класификације материјала. Дакле, упоређују се речничке дефиниције глагола любить (ся) и волети (се), њихов валенцијски и прагматички потенцијал, као и ограничења у употреби, те предлажу одрећени маркери који могу представљати поредбену и класификациону матрицу приликом потоње анализе како граматичких деривата посматраних лексема, тако и свих других које спадају у дату лексичко-семантичку групу.

Кључне речи: позитивна осећања, глаголи любить(ся) и волети (се), морфосинтаксичке особине, валенцијска структура, перформативи, руски и српски језик

1 tijana.balek@ff.uns.ac.rs

2 Рад је настао у оквиру пројекта Стандардни српски језик: синтаксичка, семантичка и прагматичка истраживаға (бр. 178004) који финансира Министарство просвете, науке и технолошког развоја Републике Србије. 


\section{1. Уводна запажања}

Поседовање и изражавање осећања својствено је сваком живом бићу. Оно што људе издваја јесте могућност да осећања (како позитивна тако и негативна) вербализују на различите начине. Предмет нашег истраживања представљају два глагола којима се денотирају позитивна осећања - любить у руском језику и волети у српском, као и њихове рефлексивне форме любиться и волети се. На основу лексикографског описа те морфосинтаксичких својстава које поседују, покушаћемо да дефинишемо какве особине би могле да садрже и друге глаголске лексеме које припадају скупини позитивних осећања, с обзиром на то да две посматране имају најнеутралније значење, услед чега смо их назвали типичним (базичним) експонентима глаголске лексике позитивно денотираних осећања.

Према мишљењу Л. М. Васиљева глаголи који припадају семантичкој парадигми чији је типични (полазни, доминантни) члан глагол любить заузимају међупозицију у односу на глаголе са значењем емоционалног преживљавања и глаголе са значењем емоционалног односа (VASILJEV 1981: 108).

Уколико лингвистичку интерпретацију емоција формализујемо као скалу са два поларитета - позитивним и негативним - у којима се налазе (глаголске) лексеме одговарајућег семантичког садржаја, тада би (како је истакнуто) овде анализирани глаголи любить (ся) и волети (се) били типични представници позитивног, док би негативни могао бити репрезентован глаголима ненавидеть (друг друга) и мрзети (се) двају наведених типова емоционалног садржаја налази се и неутрална, семантички недиференцирана и емоционално необојена „зона” којој припадају лексеме чији је емоционални садржај празан и спецификује се на нивоу глаголске фразе (помоћу различитих лексичких допуна) чувствовать у руском односно осећати : осетити ${ }^{4}$ у српском језику. Поред тога, важно је нагласити да је анализирана тематска група веома продуктивна ${ }^{5}$ и да се спецификовање глаголског значења може извршити на различите начине, на што, без сумње, утиче и интензитет денотираног

3 О морфосинтаксичким, видским и акционалним особинама глагола ненавидеть (друг друга) и мрзети (се), као и њихових граматичких деривата, в. BALEK 2018: 233-253.

4 О овоме на материјалу српског језика в. више код: ŠTRBAC 2006: 73-102.

5 Уп. у српском језику нпр. жаргонизме новијег порекла попут мувати (кога), палити се на (кога), шацовати (кога), којима се денотира различит степен позитивног осећања семантичког субјекта према другом лицу/лицима, граматикализованим допунама у акузативу. Поред тога, када је реч о структури глаголске фразе којом се изражава одговарајуће осећање, треба нагласити да глагол палити се развија значење осећати страст, пожуду према коме једино уз предлог на. 
осећања, а може се изразити различитим морфосинтаксичким средствима, укључући предлошко-падежне конструкције.

\section{2. Лексикографски опис глагола любить и волети}

Посматрани глаголи любить и волети имају готово идентичну семантику и интерпретирамо их као прототипичне глаголе емоционалног садржаја с позитивним значењем јер је оно најнеутралније у погледу означавања посматраног својства - уп. лексикографске податке који се тичу глагола любить, наведене у седамнаестотомном речнику Руске академије наука Словарь современного русского литературного языка под редакцијом В. И. Чернишова: 1. Чувствовать глубокую привязанность, преданность к кому-, чему-либо, основанные на признании высокого значения, достоинства, на обших иелях, интересах и т. п. || Чувствовать склонность, привязанность к кому-либо, вытекающие из отношений близкого родства, дружбь, товарищества и т. п. Прошу любить и жаловать. Слова, употребляемые при первом знакомстве, представлении кого кому-либо. 2. Чувствовать горячую сердечную склонность, влечение к лииу другого пола. 3. Чувствовать внутреннее влечение, внутреннюю склонность, тяготение к чему-либо. || Испьлтьвать удовольствие (от созерияания, очуиения чего-либо). || Иметь пристрастие к чему-либо; отдавать предпочтение. || Быть довольным чем-либо, испьтывать удовлетворение от чего-либо. \| Ценить, признавать что-либо. 4. Предпочитать что-либо как наилучшее условие своего существования, обитания. О животных, растениях (С̌ERNIŠOV 1957/6: 428-430).

Уколико упоредимо наведену дефиницију с оном доступном у Речнику српскохрватског книжевног и народног језика (даље и RSANU), могуће је запазити да волети, осим што има мање значења, може, с једне стране, функционисати као модални глагол (кореспондент желети и $x m e m u)$, a, са друге, бити једно од средстава поређења у одговарајућим конструкцијама, уп.: I. 1. а. (некога, ређе некоме) осећати љуубав, бити пријателски расположен, наклоюен, везан осећаюима (за некога). б. марити, имати воле (за нешто), трпети, подносити (некога, нешто), осећати задовољство (у нечем). в. (о биљкама, животињама) тражити као средину, подлогу, боле напредовати (захвалујући нечему). 2. желети, хтети. 3. (понекад и са обличким обележјима поређења) нар. више (највише) волети, више (највише) желети, претпоставлати; Изр. као очи у глави, као со у очи в. око (изр.). као свиюа роткву в. ротква (изр.). II. се осећати узајамну вубав, наклоност (STEVANOVIĆ, PAVLOVIĆ i dr. 1962/2: 770-771).

Дакле, на основу наведених дефиниција можемо закључити да посматрани глаголи ипак показују одређена значењска одступања, 
која се најпре огледају у примарном значењу анализираних лексема. Код любить експлицитно је наведено да се приврженост, преданост коме, не односе искључиво на романтична осећања (штавише, уопште се не подразумева емоционална конотација већ реч може бити и о интересу), док је у речничкој одредници у српском извору емоционална компонента примарна. Поред тога, глагол любить има ширу употребу и са прагматичког аспекта јер се користи као израз који се упућује другом лицу приликом упознавања, представљања, и то у инфинитиву, као део аналитичког предиката у којем (уз глагол жаловать) представља семантичко тежиште ситуације - Прошу любить и жаловать (с друге стране, волети показује шири опсег од любить - в. ниже).

C аспекта формалне, лексичке презентације семантичког потенцијала анализираних двају глагола разлике се запажају већ на први поглед. Наиме, у српском језику постоји апсолутни кореспондент (како с формалног тако и семантичког аспекта) глагола любить. Ради се о глаголу љубити 6 , који се у савременом стандардном језику не употребљава у значењу које је карактеристично за глагол волети, јер је овај последњи „преузео” поменути семантички садржај (дакле, у периоду ранијих епоха глагол љубити употребљавао се у значењу 'волети' (према томе, еквивалентност са руским глаголом любить била је израженија), али је у синхроној перспективи дато значење архаично). Друга разлика коју је с формалне стране могуће уочити код посматраних (у највећем делу) семантичких кореспондената тиче се њихове етимологије. Наиме, глагол любить, као и сви његови деривати који нису предмет анализе, води порекло од прасловенског корена ${ }^{*} l j u b-{ }^{7}$, док се настанак глагола волети (и изведеница од наведене основе) повезује с именицом вољ $a^{8}$ (в. SKOK 1973/3: 614).

\section{3. Морфосинтаксичке особине глагола любить и волети}

\section{1. Иако припадају скупини емоционалне лексике, тешко је}

6 Дати глагол у једнотомном Речнику српскога језика Матице српске (NIKOLIĆ 2011: $646)$ у 2. и 3. значењу има емоционалну компоненту, док у примарном значи додиривати уснама, а у рефлексивној форми - међусобно изменивати пољупце. Наведена значења незнатно су модификована (сажета).

7 Примарни придев ljub мотиватор је за настанак лексема најразличитијег семантичког спектра и у српском језику: антропонима (Славољуб, Драгољуб), придева (љубичаст, љубблени), именица (љубавник, льубомора, прельба) и глагола (сљубавити се, приљубити се, тьубакати се и др.) (в. SKOK 1972/2: 337-339).

8 Лексема воља представља мотивну реч не само наведеним глаголима који ће бити разматрани, већ и следећим: саизволети, извољевати, издовољити се, удовољити, повољити, расвевољити, одобровољити, озловолити, разловољити и сл. (в. SКОК 1973/3: 614). 
утврдити у који тип предиката треба уврстити посматране лексеме. Наиме, О. Н. Селиверстова (SELIVERSTOVA 1982: 139) указала је на тешкоће у датом погледу, истакавши да глагол любить не припада стативним глаголима, али не изражава ни активност нити процес. Предикати типа любить се релативно слободно спајају с изразима попут все сильнее и сильнее 9 (срп. све јаче и јаче), што показује да денотати овог глагола нису обавезно статични и да субјект није пасиван, али, с друге стране, не денотирају ни непрестану активност, премда се могу односити на веома дуг временски период, што предикате типа любить чини најсличнијим предикатима-класама ${ }^{10}$ (SELIVERSTOVA 1982: 139-140).

На основу горенаведених лексикографских података може се уочити да су посматрани глаголи у оба језика која се пореде најчешће двовалентни ${ }^{11}$, те захтевају обавезне допуне којима се лексикализују како експеријент позитивне емоције (лексема на позицији семантичког субјекта) тако и реципијент, објекат ка којем је она усмерена (односно изазивач датог осећања / стања). У контекстуалним реализацијама глагола любить и волети експеријент је обично граматикализован номинативом и најчешће је аниматан, док је објекат ка којем је позитивно осећање усмерено (било да се одликује аниматношћу или не) граматикализован беспредлошким акузативом. Реч је о појму који је у директном контакту са носиоцем емоционалног стања и који је у потпуности обухваћен његовим емоцијама (ARSENIJEVIĆ 2006: 73).

Примери које ниже наводимо (ексцерпирани из електронских извора на руском односно српском језику (даље NKRJ односно KSSJ) и/или из различитих књижевних дела) потврђују да глаголи любить и волети имају по две обавезне допуне - једну којом се лексикализује доживљавач осећања (живо /+/ и људско /+/) - у руском језику су то заменице я (примери 1, 2, 3 и 6), они (пример 4), многие (пример 5); затим поредбена конструкција люди как люди у примеру 7, у којем је реченица парцелисана и субјект је имплицитан, те, у истом примеру, именица којом се денотира колективни субјект человечество. С друге стране, изазивачи денотираног позитивног осећања или пак особе ка којима

9 Којима се указује на повећавање интензитета.

10 Будући да се класа схвата као конструкт, уопштеност, која није једнака не само појединачном свом члану него ни већем броју чланова (класа је, заправо, апстракција вишег нивоа, која се саодноси са својим члановима, али није њихова ознака), доминантне особине овог типа предиката јесу: (1) непостојање прецизне локализованости на временској оси, (2) апстрахованост у односу на непосредно протицање у времену, (3) уопштеност, која подразумева постојање великог броја случајева реализације одговарајуће активности или процеса и др. (SELIVERSTOVA 1982: 91-93).

11 В. и одредницу глагола волети (се) дату у Речнику валениије глагола емоционалног садржаја у: ŠTRBAC 2005: 173-196. 
се оно усмерава у руском језику означавају заменица вас у акузативу без предлога (пример 1), тј. именице деньги (7), грузинскую музыку (4), современную русскую попсу (5), цветь и розы (6), односно школу (2) у истом падежном облику. УП.:

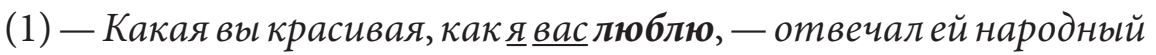
художник (NKRJ);

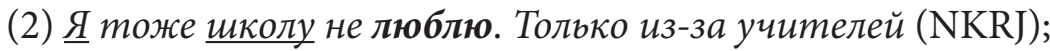

(3) Как же я люблю диалоги! (NKRJ);

(4) В обшем, почему они любят грузинскую музыку (NKRJ);

(5) Не понимаю, почему многие так не любят современную русскую nопсу (NKRJ);

(6) - Нет, я люблю йветьц, только не такие, - сказал я. - А

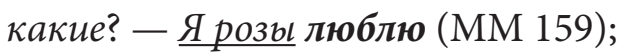

(7) [...] люди как люди. [டлюди] Любят деньги, но ведь это всегда было... Человечество любит деньги, из чего бы те ни были сделаньк... (MM 143).

Када је реч о српском језику, из примера наведених ниже запажа се да су обе обавезне допуне најчешће формализоване истоветним граматичким средствима, тачније експеријент је лексикализован именицама народ (8) и Мицо (14), односно заменицама они (9), он (10), ја (11), сви ми (12), ти (14); док је појам ка којем је позитивно осећање усмерено граматикализован акузативом без предлога: юега (8), ме (9), учитеља Грују (10), своју веренииу (11), вас (12), интервјуе (13) и ме (14).

(8) Њ. Џега је народ здраво због доброте юегове волио.

(9) Ја сам се умео наћи са селацима и они су ме волели.

(10) Он тек воли учитеља Грују, - никад га неће обићи, а да не сврати.

(11) Ца безумно волим своју вереницу. ${ }^{12}$

(12) То је због тога што вас [jа] на известан начин волим, мислим, сви ми у разреду вас волимо (ВЈА 10).

(13) Emо зашто [ја] не волим интервјуе: и онај који пита и онај који одговара труде се из петних жила да испадну што духовитији (ВЈА 16).

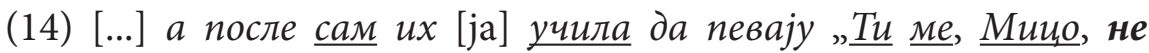
волеш..." (ВJА 23).

Из наведених примера уочава се да особа о чијем се позитивном осећању у исказу реферише не мора бити обавезно лексикализована именицом или заменицом него да информација о њој може бити

12 Примери (8)-(11) преузети су из речничке одреднице у RSANU уз наведени глагол. 
имплицитно изражена и одређеним личним глаголским облицима, у којима се у зависности од употребљених афикса за грађење одговарајућег облика утврђује његов род и број (в. примере 12, 13 и 14 ${ }^{13}$ ). Међутим, ситуација описана у примеру 14 специфична је јер реципијент даје оцену осећања експеријента, па је експеријент у вокативу. Наведено је, ипак, специфика српског језика у односу на руски јер се у руском језику осим глагола у личном глаголском облику агенс мора маркирати и заменицом / именицом, премда је у савременом језику примећена тенденција знатног одступања од датог правила.

3.2. Уколико су пак на позицији семантичког субјекта („доживљавача / експеријената”) уз глаголе волети / любить лексеме које припадају класи животиња или биљака, тада се на позицији семантичког објекта налазе именице или именичке синтагме које денотирају оно без чега одређена врста не може да опстане или пак оно што представља оптималну средину за њихов раст и развој, што га на било који начин поспешује. Примери 15 и 16 на руском језику показују, заправо, супротну ситуацију (оно што не погодује развоју) јер је реч о негацији:

(15) Растения не любят глубокой посадки; поэтому высаживать их нужно не глубже первых настоящих листьев... (NKRJ).

(16) Не любит перегрева и лосось: на нерест идет не в то время и не в те места, что заложены в его генетической программе (NKRJ).

(17) А тај мирис пловчјег меса на рибу долази отуда што и пловке воле воду... (KSSJ);

(18) Руже, каранфили и хризантеме воле доста воде; гербери и лале воле воду до трећине вазе (KSSJ);

(19) [...] ови писи могу да претрче велику километражу и веома воле воду (KSSJ).

„Доживљавачи” емоције су у наведеним примерима граматикализовани номинативом, док је вода у примерима на српском језику, као оптимална средина, беспредлошким акузативом. Изузетак представља контекстуална реализација лексеме вода у примеру (18) на српском језику, где је употребљена генитивна допуна са квантификатором доста. Потребно је посебно истаћи да се у руском језику уз негиране форме глагола по правилу употребљава допуна у генитиву. Дакле, субјекат/доживљавач одређеног емотивног стања/ осећања или пак биљка/животиња којој су неопходни одређени услови за опстанак означени су номинативом, док је особа која је изазвала такво осећање или пак средина (као услов постојања), уз негиране глаголске

13 Премда у датом примеру није реч о субјекатској допуни глагола волети. 
облике у руском језику, граматикализована генитивом, а не акузативом. ${ }^{14}$

3.3. Анализирани глаголи-хомоними поседују још неке специфичности у поређеним језицима. Наиме, у српском језику постоје одређена рекцијска својства глагола волети каква нису запажена код руског кореспондента любить. Ради се о могућности да објекат ка којем је позитивно осећање усмерено буде означен допуном у дативу:

(20) Волим му као очима у глави;

(21) Ца сам вољела своме мужу, био ми је мио;

(22) Ocјећао је да је он тој дјевојии веома волио.

Примери овога типа, условно узевши, показују да глаголу волети недостаје допуна у виду експланативне да-реченице $\left(\right.$ волети $\left.\mathrm{X}^{15}\right)$, чијим увођењем би постало јасно због чега је такво осећање усмерено на објекат, што имплицира закључак да у датој употреби волети има карактеристике непунозначних глагола. У погледу посматраних глагола Д. Гортан Премк је закључила да је акузативна допуна стандардна и очекивана, док је дативска територијално ограничена (GORTAN-PREMK 1971: 96-97). Поред тога, Гортан Премк сматра да је лексичка допуна у дативу мотивисана значењем бити наклоюен, привржен некоме и волети нешто урадити некоме (GORTAN-PREMK 1971: 96-97), што упућује на то да се (помоћу поменутог рекцијског модела) истиче да су некоме биле намењене и емоције и поступци (ARSENIJEVIĆ 2006: 77). Дакле, суштинска разлика мотивисана двама рекцијским моделима, сматра Н. Арсенијевић, састоји се у следећем: дативском рекцијом показује се да је осећање управљено на појам граматикализован дативом - показивати љубав некоме; док је акузативна усмерена на осећања субјекта, а објекат је обухваћен без икаквог ангажовања (ARSENIJEVIĆ 2006: 77).

3.4. С друге стране, запажено је да волети и любить показују модална и модалитетна својства. То посебно долази до изражаја када значење глагола волети, према речничким дефиницијама у консултованим лексикографским изворима на српском језику, постаје блиско значењу правих модалних глагола хmети и желети. У таквој употреби посматране лексеме су синсемантичне и неопходно је присуство другог глагола у глаголској фрази који је, заправо, и носилац

14 То је у руском језику посебно уочљиво код инаниматних именица код којих није присутан синкретизам генитива и акузатива, како је с именицама које означавају живо, већ акузатива и номинатива.

15 'X' се интерпретира (овде) као глагол/предикат или реченица с обликом да + презент, чиме би се могао експлицирати (ин)аниматни објекат ка којем је осећање усмерено. Даље се 'X' означава претежно глаголски облик чија се својства испитују. Примери (20)-(22) преузети су из речничке одреднице посматраног глагола наведене y RSANU. 
значења целокупног израза. Доленаведени примери илуструју да је у српском језику могућа алтернација глагола волети, желети и хтети без штете по значење реченичног садржаја, те да су у контексту у којем се реализује значење 'осећати / имати вољу, жељу, потребу' наведене глаголске лексеме синоними ${ }^{16}$. Уп.:

(23) Види се по свему, да би моја мајка волела била, да сам

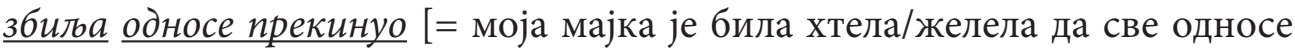
прекинем];

(24) ца баш волем $\underline{\partial а} \underline{\text { oн }} \underline{\text { yје }} \underline{\mathrm{cвe}}$, за то сам га и позвао [= ја баш хоћу/желим да он чује све...];

(25) [...] нека изађе на Дедино Брдо или на Врачар, где он воли [= нека изађе [...] где он хоће/жели];

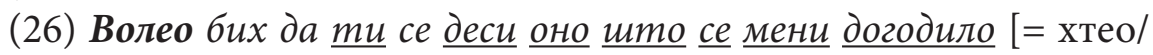
желео бих да ти се деси оно што се мени догодило]. ${ }^{17}$

Ипак, алтернација модалних глагола хтети и желети са глаголом волети карактеристичнија је за српски језик јер, како ниже наведени примери показују, у руском језику замена глагола любить модалним глаголима хотеть и желать условљава промену значења реченице у оквиру које се налазе. Наиме, уколико би се извршила дата замена, реченице на руском језику добиле би оптативно значење (изражавале би жељу, наду да ће се ситуација денотирана управним глаголом у саставу аналитичког предиката извршити, будући да у тренутку говора она није на снази), док уз глагол любить имају значење узуалности (ситуација је уобичајена, карактеристична за одговарајуће прилике (уз одређену регуларност) или се врши од раније, а њен наставак је имплициран). Уп.:

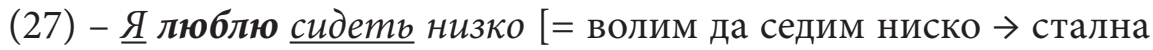
(уобичајена) квалификација активности], - проговорил артист, - $c$ низкого не так опасно падать (MМ 237); vs. Я хочу/желаю сидеть низко... [= хоћу/желим (у актуелном тренутку) да седим ниско]

(28) Любите ли вы [пить] щиампанское? [= волите ли (да пијете) шампањац $\rightarrow$ имате ли навику да пијете шампањац] (MM 307); vs. Я $\boldsymbol{x о ч} \boldsymbol{y}$ / желаю $\underline{\text { numь }}$ шампанское [= хоћу/желим (у актуелном тренутку) да пијем шампањац]

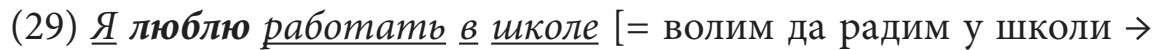
општи (непроменљиви) став према извршењу активности)]. Не знаю даже сам почему, но тянет в школу постоянно (NKRJ); vs. Я хочу/желаю

16 Иако се, без сумње, и модални глаголи хтети и желети одликују емоционалношћу, она је израженија код глагола волети.

17 Примери су преузети из речничке одреднице ове лексеме наведене у RSANU. 
работать в школе [= хоћу/желим ${ }^{18}$ (у актуелном тренутку) да радим у школи]

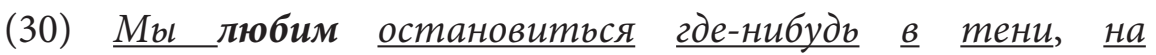
возвышенности, пить гранатовый сок и слушать звуки ночного города $[=$ волимо да се зауставимо негде у сенци, на узвишењу... $\rightarrow$ имамо навику да се зауставимо негде у сенци...] (NKRJ) vs. Mы хотим/желаем остановиться где-нибудь в тени... [= хоћемо/желимо (у актуелном тренутку) да се зауставимо негде у сенци...]

Постоје, међутим, и у српском језику случајеви када замена глагола волети модалним желети и хтети у истом контексту није могућа јер утиче на интерпретацију реализације ситуације и/или њену емоционалну обојеност. Наиме, алтернација може неповољно утицати на резултативни карактер радње и то на начин да се, као што је случај у руском језику, употребом модала хтети и желети извршење радње у великој мери релативизује. Другим речима, замена глаголских лексема имплицира да радња до говорног тренутка није извршавана те да ће агенс, условно речено, уложити известан напор да би се то постигло, док глагол волети у истом контексту сигнализује узуалност (уобичајеност) у вршењу радње. Дато се значење може описно представити као 'имати обичај', а П. Мразовић и 3. Вукадиновић глагол волети у таквој употреби називају модалитетним ${ }^{19}$ (MRAZOVIĆ, VUKADINOVIĆ 2009: 191, 195). Уп.:

(31) Највище је волела да прича пливајући (ВЈА 7) [₹ највише је хтела/желела да прича пливајући];

(32) Моја се амбиција састоји у томе што волим да чаврљам ca финим особама (BJA 9) $[\neq$... што хоћу/желим да чаврљам са финим особама];

(33) Волео је, иначе, да нас окупља й да нам чита најновије вести (BJA 32) [ Х Хтео је/Желео је, иначе, да нас окупља и да нам чита...].

Поред тога, премда у литератури нисмо наишли на сличан податак, сматрамо да би проучаване глаголске лексеме у поређеним језицима могле бити, условно, оквалификоване и као тровалентне ${ }^{20}$, 18 Уколико се употреби глагол желети, постоји могућност да активност денотирана

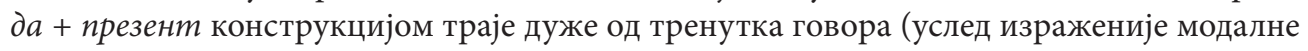
компоненте). Уп. слагање модала желети и хтети с прилогом одувек: Одувек желим да радим у школи vs. ?Одувек хоћу да радим у школи: Одувек сам хтео да радим у иколи.

19 Модалитетни глаголи су веома слични модалним, а разлика међу њима састоји се у чињеници да додаци (темпорални, локални, узрочни и др.) могу да стоје не само пре $\partial a+$ nрезент конструкције него и, знатно чешће, у оквиру ње (MRAZOVIĆ, VUKADINOVIĆ 2009: 191). Ауторке истичу да волети као самосталан глагол има значење 'осећати љубав према некоме/нечему', а као модалитетан 'имати обичај' (MRAZOVIĆ, VUKADINOVIĆ 2009: 195).

20 Дато својство присутно је код глагола волети и када се налази у саставу анали- 
посебно у случају када је у реченици експлициран узрок/изазивач глаголом денотиране ситуације као обавезан услов за њен настанак. У таквим околностима се експликација узрока/узрочника глаголске позитивно денотиране ситуације обично постиже адвербијалима због, зато што, јер (рус. из-за; за то, чmо; за). Примећујемо да волети и любить у датој употреби имају значење блиско значењу правих глагола каузираних емоционалних стања (о чему в. код: ŠTRBAC 2006). Уп.:

(34) Волим те јер ме увек саслушаш;

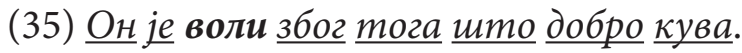

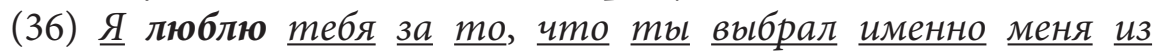
множества других (срп. Волим те јер си одабрао мене од мноштва других);

(37) 묘 люблю тебя из-за жалости (срп. Волим те из сажалеюьа);

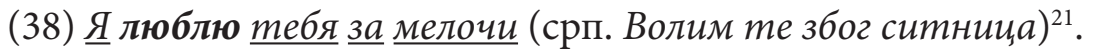

3.5. Уочили смо још један аспект прагматичке вредности глагола любить и волети, који се тиче њихове употребе у 1. лицу једнине презента индикатива. Наиме, познато је да се тзв. перформативним глаголима врши утицај на примаоца информације, желећи да овај изврши какву наредбу, испуни молбу, жељу, да савет итд. ${ }^{22}$

С обзиром на то да се посматрани глаголи користе у првом лицу једнине, што је у словенским језицима један од основних услова реализације перформативности, и то уз обавезно лексичко маркирање „примаоца” вербализоване информације, сматрамо да су изрази којима се означава поседовање јаких позитивних (не обавезно и романтичних) осећања Я люблю тебя односно Волим те такође једна врста перформативних исказа - својеврсна индиректна наредба. Разлог наведене интерпретације њихове прагматике састоји се у чињеници да приликом нормалне (устаљене, општеприхваћене) комуникативне активности увек када пружи вербални „доказ” јачине привржености адресату, адресант очекује потврдан одговор, тј. да се узврати истом мером (идентичним осећањима), што се вербализује нпр. изразима: $И$ я тебя односно Ија тебе. Дакле, адресат осећа обавезу да испуни очекивања адресанта - другим речима, да изврши добијену индиректну наредбу јер

тичких предиката, те испољава своју синсемантичност. То, ипак, зависи од управног глагола у аналитичкој предикатској јединици чији је модал волети интегрални члан. Уп. нпр. Волим да шетам после подне са тобом (пример наш), где допуна у виду социјативног инструментала може да се, условно и у извесном (ширем) смислу, посматра и као допуна глагола волети.

21 Примери (34)-(38) су наши.

22 Говорни жанр изјаве љубави (рус. объяснение в любви) припада примарним говорним жанровима, насталим у условима непосредног говорног општења (BAHTIN 1979: 239). 
је потврдан одговор имплициран, али и културолошки условљен, стога што говорнику ${ }^{23}$ није важно само да покаже своја осећања већ и да утврди шта прималац вербализоване емоције осећа према њему (GALJAMOVA 2010: 34).

Иако је перформативна компонента мање изражена у изразу $I$ love you (рус. Я люблю тебя; срп. Волим mе) него у I now pronounce you man and wife (рус. Я объявляю вас мужем и женой; срп. Проглашавам Вас мужем и женом), она је, сматра Е. Ганс, латентно присутна јер се од другог лица очекује да „учествује” у осећању и да афирмативан одговор (GANS 1995).

\section{4. Рефлексивни облици с постфиксом -ся и морфемом се}

Рефлексивне форме посматраних глагола - любиться и волети $c e^{24}$ - могу да имплицирају множину актаната, што се најчешће манифестује као реципрочност (односно узајамно равноправно учествовање у осећању, тј. (обострано) улагање напора како би се задржао жељени квалитет односа). Другим речима, додавањем морфеме ce „добија се узајамно-повратно значење и множински облик”, а да би то било могуће, мора бити задовољен важан услов - „бити исте врсте” (ŠTRBAC 2006: 86). ${ }^{25}$

Ниже наведенипримерипоказујудасереципрочностпосматраних глагола у српском језику реализује, условно речено, „природније” него у руском, где је често потребно експлицирати је на нивоу реченице, без обзира на то што је она већ формално изражена постфиксом -ся. Осим тога, да би се означила реципрочност глаголске семантике, и уједно множина актаната, у руском језику се користи и конструкција са сложеном узајамно-повратном заменицом друг друга (што се на српски може превести као једно друго, међусобно итд.). Међутим, реципроцитет код глагола любиться, иако јесте примарно значење, у четворотомном речнику Словарь русского языка (JEVGENJEVA 1999), обележен је као застарела форма и народски облик ${ }^{26}$. Постфиксална варијанта любиться

23 Интенција у датом говорном чину може се разликовати у зависности од пола говорника, те тако Н. Ш. Гаљамова истиче да је за мушки пол карактеристично тзв. объяснение в любви, док је женском својствено тзв. признание в любви (о семантичко-прагматичким условима реализације овог говорног жанра в. више код: GALJAMOVA 2010: 29-35), премда се оба на српски језик преводе као изјавъиваюе тьубави.

24 О рефлексивним формама глагола с проучаваном семантиком у српском језику в. више код: ŠTRBAC 2007.

25 Наведено важи за све глаголе које у раду посматрамо.

26 Дата околност свакако утиче на фреквенцију у свакодневној употреби. Наиме, у NKRJ любиться је присутан с фреквенцијом 225, док је любить неупоредиво заступљенији - присутан је у више од 163800 реализација. 
може имати и допуну у инструменталу, која је лексикализована изразима типа брат с сестрою, [ты] с Настенькой и сл. ${ }^{27}$ (в. ниже).

(39) - От же як любятся брат с сестрою... (NKRJ);

(40) - Если жена ㄸууим любится, то во Франции говорят, что она мужу рога наставляет (NKRJ);

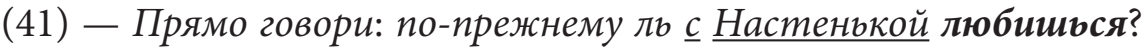
$(\mathrm{NKRJ})$;

(42) Ведь вы друг по друге сохнете; въи любили друг друга прежде; любитесь же с богом и теперь - кто вам мешает? (NKRJ);

(43) Но не о том, где любится, где нет (NKRJ);

(44) - Тамо су се волели Алфа Ромео и Булијета Спринт! јака ствар! (BJA 85);

(45) Ана је сматрала да је зло још веће. Не воле се више. Петар се још држи поносито и ћути (KSSJ);

(46) Воле се они. Велики су другови (KSSJ);

(47) ... кад младост иьвета, кад зачиюу велике идеје и воли се да би се волило (KSSJ);

(48) - Када се тако воли, воли се увек! - узвикну он. (KSSJ).

С друге стране, исказивање реципрочности рефлексивних глагола сличним изразима у српском језику може се сматрати плеоназмом. Уп.: (49) Волели сте једно друго / се међусобно раније, волите cе поново // Волели сте се раније, волите се поново.

\section{5. Закључне напомене}

Спроведена анализа је показала да постоје особине заједничке за глагол любить (ся) и волети (се) те да се оне односе, у првом реду, на укупну семантичку вредност посматраних глагола - позитивну емоционалну обојеност, као и, најчешће, моделе граматикализације и аниматни тип допуна. Наиме, субјекат је у највећем броју случајева граматикализован номинативом (живо /+/ и људско /+/), а реципијент (прималац/објекат љубави) беспредлошким акузативом, премда се у српском може срести и допуна у дативу (из синхроне перспективе застарела). Поред тога, у српском језику могућа је алтернација глагола волети модалним глаголима хтети и желети, па сматрамо да волети у значењу 'осећати/имати вољу, жељу, потребу' показује особине модалних 27 Што би се на српски језик могло пренети употребом глагола волети (не: волети се) и допуне у акузативу (срп. - Право говори: Да ли као и раније волии Настјенку?), а не инструментала с предлогом, јер волети се (када је на позицији семантичког субјекта живо /+/ и љьудско /+/) уз наведени тип лексичке предлошко-падежне допуне $(\mathrm{c} / \mathrm{ca}+$ инструментал живо /+/) има (и) значење водити льубав (с неким). Уп. дослован превод примера 41 на српски језик: - Право говори: да ли се као и раније волиш с Настјенком $(\rightarrow$ Да ли као и раније водите љубав)? 
глагола, а у 'имати обичај' припада тзв. модалитетним глаголима (в. горе). Сасвим супротно, глагол любить се не може заменити ни са једним модалним, али показује особине модалитетних глагола (према примењеним критеријумима).

Нерефлексивне варијанте анализираних лексема (любить и волети) припадају перформативним глаголима, с интенцијом адресанта да добије признање (потврду) осећања адресата на основу сопствених, односно ради се о својеврсној индиректној наредби, будући да се од адресата очекује да потврди осећања адресанта, да у њима равноправно учествује. C друге стране, запажено је да се рефлексивни облици любиться и волети се различито понашају у контексту. Наиме, любиться уз допуну у инструменталу с предлогом $c / c a$, када је семантички објекат формализован лексемом која денотира живо /+/ и људско /+/, не имплицира да је реч о вођењу љубави, док волети се уз истоветан тип допуне подразумева формализацију коагенса у активности наведеног типа.

Дакле, приликом потоњих истраживања како граматичких деривата любить (ся) и волети (се) тако и других који чине посматрану тематску класу, осим указивања на формално-лексичке специфичности презентације семантичког садржаја, требало би проверити степен кореспонденције грађе према уоченим параметрима: (1) број и начин граматикализације лексичких допуна глагола, (2) постојање могућности супституције с модалним глаголима и/или способност реализације у својству модалитетних (и ограничења у датом погледу), функционисање као перформативи. Несумњиво је да ће подробна анализа изведеница донети нове закључке који ће допринети успостављању кореспонденције у посматраној тематској класи и пружити додатна запажања на основу којих ће се проширити списак демаркационих критеријума примењивих у даљим истраживањима.

\section{Цитирана литература}

ARSENIJEVIĆ 2006: ARSENIJEVIĆ, Nada. „O glagolima voleti i zaljubiti se”. U: Piper, Predrag (ur.). Kognitivnolingvistička proučavanja srpskog jezika (str. 71-83). Beograd: Srpska akademija nauka i umetnosti, 2006. [orig.] АРСЕНИЈЕВИЋ, Нада. „О глаголима волети и залубити се”. У: Пипер, Предраг (ур.). Когнитивнолингвистичка проучаваюа српског језика (стр. 71-83). Београд: Српска академија наука и уметности, 2006.

BALEK 2018: BALEK, Tijana. „Bazični glagoli emocionalnih odnosa s negativnim denotativnim značenjem u ruskom i srpskom jeziku (nenavidet : mrzeti; nenavidet drug druga : mrzeti se)”. Filolog, 18 (2018): str. 233-253. [orig.] БАЛЕК, Тијана. „Базични глаголи емоционалних односа с негативним денотативним значењем у руском и српском језику (ненавидеть : 
мрзети; ненавидеть друг друга : мрзети се)”. Филолог, 18 (2018): стр. 233-253.

BAHTIN 1979: BAHTIN, Mihail Mihajlovič. „Problema rečevih žanrov”. V: Bahtin, Mihail Mihajlovič. Estetika slovesnogo tvorčestva (str. 237-280). Moskva: Iskustvo, 1979. [orig.] БАХТИН, Михаил Михайлович. „Проблема речевых жанров”. В: Бахтин, Михаил Михайлович. Эстетика словесного творчества (стр. 237-280). Москва: Искусство, 1979.

GALJAMOVA 2010: GALJAMOVA, Nurija Šajhrazijevna. „Pervični rečevoj žanr «Objasnenie, priznanie v ljubvi»: lingvokulturologičeski, funkcionalno-pragmatičeski aspekti”. Mir ruskogo slova, 4 (2010): str. 29-35. [orig.] ГАЛЛЯМОВА, Нурия Шайхразиевна. „Первичный речевой жанр «Объяснение, признание в любви»: лингвокультурологический, функционально-прагматический аспекты”. Мир русского слова, 4 (2010): стр. 29-35.

GANS 1995: GANS, Eric. „I love you”. Chronicles of Love \& Resentment. <http://anta hropoetics.ucla.edu/views/vw4/> 07.10.2020.

GORTAN-PREMK 1971: GORTAN-PREMK, Darinka. Akuzativne sintagme bez predloga u srpskohrvatskom jeziku. Beograd: Institut za srpskohrvatski jezik, 1971. [orig.] ГОРТАН-ПРЕМК, Даринка. Акузативне синтагме без предлога у српскохрватском језику. Београд: Институт за српскохрватски језик, 1971.

MRAZOVIĆ, VUKADINOVIĆ 2009: MRAZOVIĆ, Pavica i Zora VUKADINOVIĆ. Gramatika srpskog jezika za strance. Sremski Karlovci - Novi Sad: Izdavačka knjižarnica Zorana Stojanovića, 2009.

SELIVERSTOVA 1982: SELIVERSTOVA, Olga Nikolaevna. Semantičeskie tipi predikatov. Moskva: Nauka, 1982. [orig.] СЕЛИВЕРСТОВА, Ольга Николаевна. Семантические типы предикатов. Москва: Наука, 1982.

ŠTRBAC 2005: ŠTRBAC, Gordana. „Prilog izradi rečnika valencije glagola emocionalnog sadržaja”. Prilozi proučavanju jezika, 36 (2005): str. 173-196. [orig.] ШТРБАЦ, Гордана. „Прилог изради речника валенције глагола емоционалног садржаја”. Прилози проучавағу језика, 36 (2005): стр. 173-196.

ŠTRBAC 2006: ŠTRBAC, Gordana. „O valentnosti glagola emocionalnog sadržaja u srpskom jeziku”. Zbornik Matice srpske za filologiju i lingvistiku, XLIX/2 (2006): str. 73-102. [orig.] ШТРБАЦ, Гордана. „О валентности глагола емоционалног садржаја у српском језику”. Зборник Матице српске за филологију и тингвистику, XLIX/2 (2006): стр. 73-102.

ŠTRBAC 2007: ŠTRBAC, Gordana. „Refleksivna upotreba glagola emocionalnog sadržaja u srpskom jeziku”.Godišnjak Filozofskog fakulteta u Novom Sadu, 32 (2007): str. 341-353. [orig.] ШТРБАЦ, Гордана. „Рефлексивна употреба глагола емоционалног садржаја у српском језику”. Годишюак Филозобског факултета у Новом Саду, 32 (2007): стр. 341-353.

VASILJEV 1981: VASILJEV, Leonid Mihajlovič. Semantika ruskogo glagola. Moskva: Visšaja škola, 1981. [orig.] ВАСИЛЬЕВ, Леонид Михайлович. Семантика русского глагола. Москва: Высшая школа, 1981. 


\section{Извори}

BJA - KAPOR, Momo. Beleške jedne Ane. [orig.] КАПОР, Момо. Белешке једне Ане. $<$ http://www.antologijasrpskeknjizevnosti.rs> 07.10.2020.

ČERNIŠOV 1957/6: ČERNIŠOV, Vasilij Iljič (red.). Slovar sovremenogo ruskogo literaturnogo jazika. Tom 6. Moskva - Leningrad: Izdatelstvo Akademii Nauk SSSR, 1957. [orig.] ЧЕРНЫШЁВ, Василий Ильич (ред.). Словарь современного русского титературного языка. Том 6. Москва - Ленинград: Издательство Академии Наук СССР, 1957.

JEVGENJEVA 1999: JEVGENJEVA, Anastasija Petrovna (red.). Slovar ruskogo jazika: $v$ 4-h t. Moskva: Ruski jazik - Poligrafresursi, 1999. ЕВГЕНЬЕВА, Анастасия Петровна (ред.). Словарь русского языка: в 4-х $m$. Москва: Русский язык - Полиграфресурсы, 1999.

KSSJ - Korpus savremenog srpskog jezika na Matematičkom fakultetu Univerziteta u Beogradu. [orig.] КССJ - Корпус савременог српског језика на Математичком факултету Универзитета у Београду. <http://www.kora pus.matf.bg.ac.rs/korpus/mainmenu.php $>01.10 .2020$.

MM - BULGAKOV, Mihail Afanasjevič. Master $i \quad$ Margarita. [orig.] Булгаков, Михаил Афанасьевич. Мастер и Маргарита. <http://www. bulgakov.ru/pdf/Master-i-Margarita.pdf>07.10.2020.

NIKOLIĆ 2011: NIKOLIĆ, Miroslav (ur.). Rečnik srpskoga jezika. Novi Sad: Matica srpska, 2011. [orig.] НИКОЛИЋ, Мирослав (ур.). Речник српскога језика. Нови Сад: Матица српска, 2011.

NKRJ - Nacionalni korpus ruskogo jazika. [orig.] НКРЯ - Национальный корпус русского языка. <https://ruscorpora.ru/new/search-main.html> 01.10.2020.

SKOK 1972/2: SKOK, Petar. Etimologijski rječnik hrvatskoga ili srpskoga jezika. Knjiga druga K - poni'. Zagreb: Jugoslavenska akademija znanosti i umjetnosti, 1972.

SKOK 1973/3: SKOK, Petar. Etimologijski rječnik hrvatskoga ili srpskoga jezika. Knjiga treća poni ${ }^{2}$ Ž. Zagreb: Jugoslavenska akademija znanosti i umjetnosti, 1973.

STEVANOVIĆ, PAVLOVIĆ i dr. 1962/2: STEVANOVIĆ, Mihailo, Milivoj PAVLOVIĆ i dr. Rečnik srpskohrvatskog književnog i narodnog jezika. Tom 2. Beograd: Institut za srpskohrvatski jezik, 1962. [orig.] СТЕВАНОВИЋ, Михало, Миливој ПАВЛОВИТ и др. Речник српскохрватског књижевног и народног језика. Том 2. Београд: Институт за српскохрватски језик, 1962. 
Tijana Balek

MORPHOSYNTACTIC AND PRAGMATIC FEATURES OF VERBS LJUBIT'(SJA) AND VOLETI (SE) AS EXPONENTS OF VERBS WITH THE MEANING OF POSITIVE EMOTIONS IN RUSSIAN AND SERBIAN

In the paper we examine lexicographic, morphosyntactic and pragmatic features of the verbs that denote positive emotions in Russian and Serbian - ljubit' and voleti, as well as their reflexive variants ljubit'sja and voleti se. The main objective of our research is to define characteristics that could be used as demarcation criteria for further researches of the discussed thematic group of verbs. We compare lexicographic definitions of ljubit'(sja) and voleti (se) from representative Russian and Serbian dictionaries, their valence and pragmatic potential, but we also present their limitations in use. The results of the conducted analysis can be used as a base for examining grammatical and semantic derivatives of ljubit'(sja) and voleti (se) or can be implemented in investigation of the entire thematic field of positive emotions.

Keywords: positive emotions, verbs ljubit'sja and voleti se, morphosyntactic features, valence, performatives, Russian and Serbian 